\title{
Scottish general practitioners' attitudes and knowledge in respect of prescribing costs
}

\author{
M Ryan, B Yule, C Bond, R J Taylor
}

\begin{abstract}
The government's proposal to introduce drug budgets will compel general practitioners to consider the financial consequences of prescribing. A survey was carried out of general practitioner principals in Grampian and a sample elsewhere in Scotland to examine their attitudes towards considering costs when prescribing and assess the accuracy of their knowledge of drug costs. Most general practitioners agreed that costs should be borne in mind when choosing medicines but their knowledge of drug costs was often inaccurate. Only one third of estimates were correct to within $25 \%$ of the actual cost, and there was a tendency to overstate the cost of cheap drugs and understate the cost of expensive ones. Some general practitioners were not aware of the relative prices of competing products or proprietary products and generic equivalents.

The findings highlight the importance of providing general practitioners with readily accessible and up to date information on drug costs if prescribing budgets are to work.
\end{abstract}

\section{Introduction}

Continued concern about the size of the NHS drugs bill has led the government to announce that from 1992 in Scotland general practitioners will be subject to prescribing budgets. ' For most general practitioners these budgets will be "indicative" - that is, prescribing costs will be expected to come within a specified budgetary limit. Larger practices which opt to participate in the practice budgets scheme will be paid an amount to cover prescribing costs.

Practices which exceed their indicative or practice budgets will be offered advice and may have their prescribing subjected to peer review. If such an investigation finds that a member or members of the practice have been overprescribing sanctions may be applied.

Budgets will compel general practitioners to consider the financial consequences of their prescribing to a greater extent than ever before. This raises two crucial questions: Do general practitioners accept the need to consider costs when prescribing? and How well do they know the cost of the drugs they prescribe? This paper examines these issues based on a survey of general practitioner principals in Grampian and elsewhere in Scotland.

Department of Genera Practice, University of Aberdeen, Foresterhill

Health Centre, Aberdeen AB9 2ZD

C Bond, BPHARM, research assistant

$\mathrm{R} J$ Taylor, $\mathrm{MD}$, senior lecturer

Correspondence to: $\mathrm{Ms}$ Ryan.

Br.Med F 1990;300:1316-8 \begin{abstract}
questionnaire was sent to all 273 general practition principals in Grampian in October 1986. To whether these doctors were representative of Scottish doctors more generally the questionnaire was also sent to a random sample of 94 Scottish principals.

Methods
\end{abstract}

The questionnaire asked general practitioners about their attitudes towards prescribing costs and assessed their knowledge of the net ingredient cost of 21 drugs. The drugs were chosen to include products from different therapaeutic groups - namely, ulcer healing preparations (ranitidine, cimetidine); preparations for allergic disorders (chlorpheniramine maleate, terfenadine, sodium cromoglycate); analgesics (codydramol, co-proxamol, paracetamol); non-steroidal anti-inflammatory drugs (ibuprofen, Brufen (ibuprofen), Naprosyn (naproxen), mefenamic acid); antibiotics (ampicillin, Penbritin (ampicillin), amoxycillin, penicillin V); nervous system preparations (diazepam); and cardiovascular preparations (enalapril, glyceryl trinitrate, Transiderm-Nitro (glyceryl trinitrate), nifedipine). Cheap and expensive preparations, commonly and less commonly used preparations, generic and proprietary preparations, competing products, and established and newly marketed preparations were covered by this selection.

Additional information was obtained, for Grampian doctors only, about characteristics of the general practitioners-for example, year qualified, sex, number of further qualifications, location of practice, size of partnership-and their frequency of prescribing each of the 21 drugs.

It would not have been reasonable to expect general practitioners to know the exact cost of drugs (there are often discrepancies between published sources of cost information - for example, British National Formulary, Monthly Index of Medical Specialities, Chemist and Druggist Price List). Hence in keeping with other studies of doctors' perceptions of costs ${ }^{3.5}$ we accepted as accurate those estimates which were within $25 \%$ of the actual cost (obtained from the Prescription Pricing Bureau, Aberdeen). Doctors were urged not to estimate the cost of products they had never prescribed.

\section{Results}

A total of 223 Grampian doctors (82\%) and $72(77 \%)$ of the Scottish sample returned the questionnaire. Of these, $213(96 \%)$ and $68(94 \%)$ respectively attempted the cost estimation section.

Attitudes towards drug costs in the Grampian and Scottish samples were very similar, and the differences between them were not significant at the $5 \%$ level when using $\chi^{2}$ tests (table I). Three quarters of the Grampian principals $(169 ; 76 \%)$ and two thirds of the Scottish sample $(47 ; 66 \%)$ agreed that costs should be taken into account when prescribing; 161 Grampian doctors (73\%) and 54 Scottish doctors $(75 \%)$ thought that prescribing costs could be reduced without affecting patient care, and the same proportions saw better cost information as a means of achieving this.

Grampian and Scottish doctors' knowledge of drug costs was virtually identical (table II). Around one third of all cost estimates were accurate to within 25\% 
of the actual cost, roughly $44 \%$ were overestimates, and $24 \%$ were underestimates. With respect to individual products $t$ tests showed no significant differences in the average cost estimates of the Grampian

TABI.E I-General practitioners' attitudes towards prescribing costs. Figures are numbers (percentages) of doctors

\begin{tabular}{|c|c|c|c|c|}
\hline & Agree & Uncertain & Disagree & $\begin{array}{l}\text { Significance of } \\
\text { difference }\end{array}$ \\
\hline & \multicolumn{4}{|c|}{$\begin{array}{l}\text { When deciding on best treatment for an individual } \\
\text { patient the doctor should normally take cost into } \\
\text { aciount }\end{array}$} \\
\hline \multirow[t]{2}{*}{$\begin{array}{l}\text { (irampian }(\mathrm{n}=223) \\
\text { Scotland }(\mathrm{n}=71)\end{array}$} & $\begin{array}{r}169(76) \\
47(66)\end{array}$ & $\begin{array}{ll}6 & 3 \\
6 & 8\end{array}$ & $\left.\begin{array}{l}48(22) \\
18(25)\end{array}\right\}$ & $y^{\prime}=5 \cdot 40 ; p=0 \cdot 07$ \\
\hline & $\begin{array}{l}\text { Most gene } \\
\text { prescribir }\end{array}$ & $\begin{array}{l}\text { ral practition } \\
\text { eg costs witho }\end{array}$ & $\begin{array}{l}\text { uers could rea } \\
\text { ut adiersely }\end{array}$ & $\begin{array}{l}\text { uce substantially thei } \\
\text { affecting patient care }\end{array}$ \\
\hline \multirow[t]{2}{*}{$\begin{array}{l}\text { Grampian }(\mathrm{n}=222) \\
\text { Scotland }(\mathrm{n}=72)\end{array}$} & $\begin{array}{r}161 \div 73 \\
5475\end{array}$ & $\begin{array}{l}32(14) \\
10(14)\end{array}$ & $\begin{array}{r}29 \\
8(11)\end{array}$ & $\gamma=0.22 ; p=0.90$ \\
\hline & $\begin{array}{l}\text { Prozidins } \\
\quad d r u\end{array}$ & $\begin{array}{l}\text { general prac } \\
\text { g costs would }\end{array}$ & $\begin{array}{l}\text { titioners wit } \\
\text { lower the co }\end{array}$ & $\begin{array}{l}\text { i more information on } \\
\text { it of prescribing }\end{array}$ \\
\hline $\begin{array}{l}\text { Grampian }(n=223) \\
\text { Scotland }(n=71)\end{array}$ & $\begin{array}{r}161(72) \\
53(75)\end{array}$ & $\begin{array}{l}36(16) \\
10(14)\end{array}$ & $\begin{array}{r}26(12) \\
8(11)\end{array}$ & $\gamma^{\prime}=0.20 ; p=0.91$ \\
\hline
\end{tabular}

TABLE II - Accuracy of general practitioners' estimates of drug costs. Figures are numbers (percentages) of estimates

\begin{tabular}{lll}
\hline & $\begin{array}{c}\text { Grampian } \\
(\mathrm{n}=4293)\end{array}$ & $\begin{array}{l}\text { Scotland } \\
(\mathrm{n}=1243)\end{array}$ \\
\hline $\begin{array}{l}\text { Underestimates } \\
\text { Accurate estimates* }\end{array}$ & $1030(24)$ & $286(23)$ \\
Overestimates & $1417(33)$ & $398(32)$ \\
\hline
\end{tabular}

*Within $25 \%$ of the true cost. and Scottish samples. Table III presents results for the Grampian doctors only.

The number of replies was notably lower only for enalapril, which at the time of questioning was recently marketed and not used by $90(42 \%)$ of the doctors. The range of cost estimates for each drug was wide but included the actual cost in nearly all cases. The exception was diazepam, the cheapest product, for which all the doctors overestimated the cost.

The distribution of replies into underestimates, accurate estimates (that is, within $25 \%$ of the true cost), and overestimates varied greatly among products, from all general practitioners overestimating the cost of diazepam to $146(71 \%)$ underestimating the cost of sodium cromoglycate. There was little consistency in the accuracy of estimates within therapeutic groups, even when comparing generic and proprietary forms of the same preparation (for example, ibuprofen and Brufen, ampicillin and Penbritin). Doctors were no better informed about the cost of drugs which they prescribed frequently. "They, however, consistently understated the cost of relatively expensive drugs and overstated the cost of cheaper ones (table IV).

Some doctors were not aware of the relative prices of competing products, even when the cost differential was large. For example, 27 doctors $(13 \%)$ thought that ranitidine and cimetidine were equally costly, and 16 $(8 \%)$ thought that cimetidine was more costly; 18 doctors $(9 \%)$ thought that amoxycillin and ampicillin were equally costly, and seven (3\%) thought that ampicillin was more costly. Even more surprisingly,

TABLE III - Grampian general practitioners' perceptions of the cost of 21 drugs

\begin{tabular}{|c|c|c|c|c|c|c|}
\hline Drug & $\begin{array}{l}\text { No of } \\
\text { estimates }\end{array}$ & $\begin{array}{l}\text { Actual } \\
\text { price } \\
\text { (f) }\end{array}$ & $\begin{array}{l}\text { Range of } \\
\text { estimates } \\
(\mathfrak{f})\end{array}$ & $\begin{array}{c}\text { Mean } \\
\text { estimate } \\
\text { ( ) }\end{array}$ & $\begin{array}{l}\text { SD } \\
\text { (f) }\end{array}$ & $\begin{array}{l}\text { Median } \\
\text { estimate } \\
\text { (f) }\end{array}$ \\
\hline Enalapril (Innovace) tablets $10 \mathrm{mg} ; 28$ & 123 & $10 \cdot 40$ & $5 \cdot 00-30 \cdot 00$ & $13 \cdot 70$ & $5 \cdot 42$ & $12 \cdot 00$ \\
\hline Diazepam tablets $5 \mathrm{mg} ; 90$ & 212 & $0 \cdot 14$ & $0 \cdot 20-10 \cdot 00$ & $2 \cdot 02$ & 1.62 & 1.55 \\
\hline Ranitidine (Zantac) tablets $150 \mathrm{mg} ; 60$ & 213 & $27 \cdot 43$ & $2 \cdot 50-80 \cdot 00$ & $21 \cdot 22$ & $9 \cdot 18$ & $20 \cdot 00$ \\
\hline (imetidine (Tagamet) tablets $400 \mathrm{mg} ; 60$ & 213 & $17 \cdot 80$ & $2 \cdot 00-70 \cdot 00$ & $16 \cdot 38$ & $7 \cdot 17$ & $16 \cdot 00$ \\
\hline Chlorpheniramine maleate (Piriton) tablets $4 \mathrm{mg}$; 90 & 212 & $0 \cdot 84$ & $0 \cdot 25-20 \cdot 00$ & 1.85 & 1.76 & $1 \cdot 20$ \\
\hline Terfenadine (Triludan) tablets $60 \mathrm{mg} ; 60$ & 207 & $5 \cdot 59$ & $0 \cdot 70-30 \cdot 00$ & $5 \cdot 61$ & $3 \cdot 02$ & $5 \cdot 00$ \\
\hline Transiderm-Nitro (glyceryl trinitrate) patches $5 \mathrm{mg} ; 30$ & 196 & $19 \cdot 33$ & $3 \cdot 00-60 \cdot 00$ & $14 \cdot 70$ & $7 \cdot 53$ & $13 \cdot 30$ \\
\hline Glyceryl trinitrate tablets $0.5 \mathrm{mg} ; 100$ & 213 & $0 \cdot 41$ & $0 \cdot 02-5 \cdot 00$ & 0.81 & $0 \cdot 60$ & 0.60 \\
\hline Nifedipine Adalat tablets $10 \mathrm{mg} ; 100$ & 211 & $12 \cdot 19$ & $2 \cdot 00-40 \cdot 00$ & $10 \cdot 78$ & $5 \cdot 27$ & $10 \cdot 00$ \\
\hline Co-proxamol tablets; 100 & 205 & 1.84 & $0 \cdot 80-10 \cdot 00$ & 3.41 & 1.74 & $3 \cdot 00$ \\
\hline Co-dydramol tablets; 100 & 206 & $1 \cdot 64$ & $0 \cdot 50-10 \cdot 00$ & $3 \cdot 24$ & 1.72 & $3 \cdot 00$ \\
\hline Mefenamic acid (Ponstan) capsules $250 \mathrm{mg} ; 100$ & 213 & $5 \cdot 27$ & $1 \cdot 50-20 \cdot 00$ & $6 \cdot 23$ & $3 \cdot 12$ & $6 \cdot 00$ \\
\hline Paracetamol tablets $500 \mathrm{mg} ; 100$ & 213 & 0.45 & $0 \cdot 25-12 \cdot 00$ & $1 \cdot 35$ & $1 \cdot 12$ & 1.00 \\
\hline Ihuprofen tablets $400 \mathrm{mg} ; 100$ & 204 & $3 \cdot 10$ & $0 \cdot 80-60 \cdot 00$ & 5.01 & $4 \cdot 71$ & $4 \cdot 00$ \\
\hline Brufen (ibuprofen tablets $400 \mathrm{mg} ; 100$ & 207 & $6 \cdot 07$ & $0 \cdot 80-40 \cdot 00$ & 6.96 & $3 \cdot 81$ & $6 \cdot 00$ \\
\hline Naprosyn naproxen tablets $250 \mathrm{mg} ; 100$ & 210 & $10 \cdot 76$ & $1 \cdot 00-60 \cdot 00$ & $9 \cdot 12$ & 4.93 & $8 \cdot 10$ \\
\hline Ampicillin capsules $250 \mathrm{mg} ; 28$ & 206 & $1 \cdot 18$ & $0 \cdot 30-14 \cdot 00$ & $2 \cdot 07$ & 1.75 & $1 \cdot 60$ \\
\hline Penbritin (ampicillin capsules $250 \mathrm{mg} ; 28$ & 201 & 1.99 & $0 \cdot 30-20 \cdot 00$ & $3 \cdot 23$ & $2 \cdot 07$ & $3 \cdot 00$ \\
\hline Amoxycillin capsules $250 \mathrm{mg} ; 21$ & 210 & $3 \cdot 31$ & $0 \cdot 40-24 \cdot 00$ & 3.55 & $2 \cdot 23$ & $3 \cdot 00$ \\
\hline Penicillin V tablets $250 \mathrm{mg} ; 28$ & 213 & $0 \cdot 41$ & $0 \cdot 20-10 \cdot 00$ & $1 \cdot 18$ & 0.97 & 1.00 \\
\hline Sodium cromoglycate (Intal aerosol inhaler $1 \mathrm{mg} ; \mathrm{l}$ & 205 & $12 \cdot 13$ & $1 \cdot 00-16 \cdot 00$ & $7 \cdot 29$ & $3 \cdot 30$ & $6 \cdot 50$ \\
\hline
\end{tabular}

TABLE IV - Accuracy of Grampian general practitioners' estimates of cost of 21 drugs listed in order of actual cost (cheapest to most expensive). Figures are numbers (percentages) of estimates

\begin{tabular}{|c|c|c|c|}
\hline & Underestimates & Accurate estimates ${ }^{\star}$ & Overestimates \\
\hline Diazepam $(\mathrm{n}=212)$ & 0 & 0 & $212(100)$ \\
\hline Glyceryl trinitrate $(\mathrm{n}=213)$ & $34(16)$ & $64(30)$ & $115 \quad(54)$ \\
\hline Penicillin V $(n=213)$ & $17(8)$ & $34(16)$ & $162(76)$ \\
\hline Paracetamol $(\mathrm{n}=213)$ & $4(2)$ & $21(10)$ & $188 \quad(88)$ \\
\hline Chlorpheniramine maleate $(\mathrm{n}=212)$ & $23(11)$ & $81(38)$ & $108 \quad 51$ \\
\hline Ampicillin $(\mathrm{n}=206)$ & 3316 & $47(23)$ & $126 \quad 61)$ \\
\hline Co-dydramol $(\mathrm{n}=206$ & $126)$ & 6230 & $132(64)$ \\
\hline Co-proxamol $(\mathrm{n}=205$ & 168 & $47(23)$ & $142 \quad 69)$ \\
\hline Penbritin (ampicillin $(\mathrm{n}=201$ & $18(9)$ & $54(27)$ & $129(64)$ \\
\hline Ibuprofen $(n=204)$ & $33(16)$ & $45(22)$ & $126 \quad 62)$ \\
\hline Amoxycillin $(n=210)$ & $55(26)$ & $105(50)$ & $50 \quad(24)$ \\
\hline Mefenamic acid $(n=213)$ & $36(17)$ & $100(47)$ & $77 \quad(36)$ \\
\hline Terfenadine $(\mathrm{n}=207)$ & $64(31)$ & $95(46)$ & $48 \quad(23)$ \\
\hline Brufen (ibuprofen) $(n=207)$ & $46(22)$ & $89(43)$ & $72(35)$ \\
\hline Enalapril $(\mathbf{n}=123)$ & 108 & $57(46)$ & $56 \quad 46$ \\
\hline Naprosin naproxen $(\mathrm{n}=210$ & $105(50)$ & $82(39)$ & 23 (11) \\
\hline Sodium cromoglycate $(n=205)$ & 146,71 & $57(28)$ & $2 \quad 1$ \\
\hline Nifedipine $(\mathrm{n}=211)$ & $78(37)$ & $108(51)$ & 25 (12) \\
\hline Cimetidine $(n=213)$ & $60-28$ & $132(62)$ & $21(10)$ \\
\hline Transiderm-Nitro (glyceryl trinitrate $)(n=196)$ & $102(52)$ & $74(38)$ & $20(10)$ \\
\hline Ranitidine $(\mathbf{n}=213)$ & $113(53)$ & $89(42)$ & $11 \quad 5$ \\
\hline
\end{tabular}

$\star$ Within $25 \%$ of the true cost. some doctors were unaware that proprietary products are more expensive than generic equivalents. For instance, $25(12 \%)$ thought that Brufen and ibuprofen were equally costly, and five $(2 \%)$ thought that ibuprofen was more costly. Similarly, 16 doctors $(8 \%)$ thought that Penbritin and ampicillin cost the same, and $10(5 \%)$ believed that ampicillin was more expensive.

Multiple regression analysis showed little association between the accuracy of general practitioners' cost estimates and their individual or practice characteristics. ${ }^{6}$

\section{Discussion}

The finding that Scottish general practitioners' perceptions of drug costs are often inaccurate is consistent with other studies in Britain. ${ }^{*}$ Given the view of most doctors in our study that drug costs should be borne in mind when choosing a patient's treatment, this may have important implications for 
the efficiency of prescribing. Overestimating the cost of cheap drugs and underestimating the cost of expensive ones may bias general practitioners' choices towards higher cost products, thus inflating the NHS drugs bill. A future paper will investigate the relation between general practitioners' perceptions of costs and their prescribing patterns.

This study highlights a demand among Scottish general practitioners for better information about drug costs. The information which they currently receive is limited to total numbers of prescriptions and costs for the doctors themselves, their practice and health board, and for Scotland as a whole. There are, however, plans to introduce in 1990 a more detailed information system for Scottish general practitioners, similar to the prescribing analyses and cost (PACT) system recently implemented in England.

There are also plans to include drug costs in the computerised module of the general practice administration system for Scotland (GPASS) and to extend the viewdata computer system (VADIS) to an an increasing number of general practitioners in Scotland. ${ }^{1}$ The viewdata computer system would provide doctors with instant up to date information on clinical attributes of drugs as well as the relative costs of products with the same therapeutic effects. Nevertheless, as only $37 \%$ of practices in Scotland are currently computerised (West Coast Computer Consortium, Paisley, personal communication) a major investment will be required to provide these systems and update them regularly.
Given the deficiencies in general practitioners' knowledge of drug costs identified in this paper, such an investment may be necessary if the government's proposals for prescribing budgets are to work.

We are greatly indebted to the general practitioners who provided the information for this study. We also thank Ianthe Fordyce, John Howie, Graham Calder, and members of the Health Economics Research Unit for comments on earlier versions of the paper. The main study ${ }^{2}$ was funded by a project grant from the Scottish Home and Health Department, and the Health Economics Research Unit is supported by core funding from the Scottish Home and Health Department.

1 Secretaries of State for Health, Wales, Northern Ireland, and Scotland. Working for putients. London: HMSO), 1989. (Cmnd 555

2 Tavlor RJ, Bond C. A study of changes in the prescribing habits of general practitioners. Report from the department of general practice, University of Aberdeen, to the Scottish Home and Health Department. Limited circulation.

3 Long $M J$, Cummings $K M$, Frisof $K B$. The role of perceived price in physicians' demand for diagnostic tests. Med Care 1983;21:243-50.

+ Robertson WO. Costs of diagnostic tests: estimates by health professionals. Hed Care 1980;18:556-9.

5 Skipper JK, Smith G, Mulligan JL, Garg ML. Physicians' knowledge of cost: the case of diagnostic tests. Inquiry 1976;12:194-8.

6 Ryan M, Yule B, Bond C, Tavlor R. Prescribing costs: a study of Scoutish general

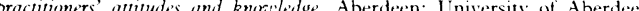
practthoners' attitudes and knoxiledge. Aberdecn: Unversity of Aberdeen, Rowe J Heacth Economics Research Unir discussion paper $05 / 89$. Joun , Macvicar S. Doctors knowledge of the cost of common medication.

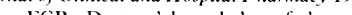

cost medical care. Med Educ $1985: 19: 113-7$

Accepted 22 Februar 1990

\section{Screening in Practice}

\section{Health checks for adults}

\author{
Godfrey Fowler, David Mant
}

\section{Which tests are worth while?}

Prevention and health promotion are now with us. They are included in the new terms of service of general practitioners, and all patients in the 16-74 year age group who have not been seen for three years must be offered a "health check." Most doctors will be aware that the validity of this recommendation is open to doubt. There is considerable concern about the efficacy, cost effectiveness, and feasibility of such an exercise, but it is wrong to dispose of the baby as well as the bathwater. Some tests are worth while (box): properly organised screening for smoking habit, blood pressure, cervical cancer, and breast cancer saves lives and prevents unnecessary suffering. Detailed information on appropriate screening intervals can be found in the references given in this article and more information on test efficacy in the article on the theory of screening. ${ }^{\prime}$ This paper discusses some of the practical issues to be considered in making screening successful in general practice.

Imperial Cancer Resed Fund General Practice Research Group, University Department of Community Medicine and General Practice, Radcliffe Infirmary, Oxford OX4 6HE

Godfrey Fowler, FRCGP, reader in general practice David Mant, MRCGP, lecturer in general practice

Correspondence to: Dr Godfrey Fowler.

\section{Practical problems}

The most important practical problems facing general practitioners in the implementation of screening programmes are summarised in table I.

\section{RECRUITMENT}

A major problem with postal recruitment and with assessing coverage is accurate registration.' Little can be done about patient mobility, but motivated reception staff can make a great contribution to maintaining correct addresses. When prescriptions are

\section{Worthwhile mass screening programmes}

- Smoking habit

- Hypertension

- Cervical cancer

- Breast cancer (mammography)

- Alcohol consumption

\section{Possible mass screening programmes}

- Hyperlipidaemia (? adequate resources for management are available)

- Obesity (? effective intervention is possible)

- Faecal occult blood (if results of randomised trials are favourable)

\section{Unnecessary mass screening programmes}

- Proteinuria

- Haematuria (but selective urine analysis in

- Glycosuria elderly patients may be worth while

- Bacteriuria and merits further research) written on desk computers linked to the main register patients often point out an incorrect address on the prescription during the consultation. Accurate registers also allow identification and targeting of high risk groups.

QUALITY ASSURANCE

Quality assurance depends primarily on good training. This means training general practitioners in the practical theory and management of screening programmes. It also means that all staff must be 